Pozytonowa tomografia emisyjna (PET) jest nowym, nieinwazyjnym badaniem czynnościowym, którego zastosowanie w ocenie klinicznego stopnia zaawansowania nowotworów, rozpoznawaniu wznowy i monitorowaniu leczenia ciągle wzrasta. Połączenie badania PET $z$ tomografią komputerową (PET/CT) zwiększa możliwości diagnostyczne metody. $W$ pracy $w$ zwięzły sposób przedstawiono zastosowania techniki PET/CT w podstawowych grupach nowotworów wieku dziecięcego. Artykuł omawia zastosowanie badania PET za pomocą FDG i innych - nowych znaczników oraz perspektywy rozwoju tej techniki. Badanie PET/CT w onkologii pediatrycznej może skutecznie wspomagać inne dotychczas stosowane badania diagnostyczne. W Polsce badanie PET/CT powinno znaleźć szersze zastosowanie zwłaszcza u dzieci z chtoniakami, guzami ośrodkowego układu nerwowego, neuroblastoma, guzem Wilmsa, guzami kości i tkanek miękkich.

Słowa kluczowe: pozytonowa tomografia emisyjna, tomografia komputerowa, onkologia pediatryczna.

\section{Utility of positron emission tomography in pediatric oncology}

\author{
Zastosowanie pozytonowej tomografii emisyjnej w onkologii \\ dziecięcej
}

Zbigniew Kulaㄹ, Ineza Szafrańska-Komarowska², Bogdan Małkowski

1Zakład Endoskopii, Centrum Onkologii im. prof. F. Łukaszczyka w Bydgoszczy 2Oddział Dziecięcy, Publiczny Specjalistyczny Zakład Opieki Zdrowotnej im. dr. L. Błażka w Inowrocławiu

${ }^{3}$ Zakład Medycyny Nuklearnej, Centrum Onkologii im. prof. F. Łukaszczyka w Bydgoszczy

\section{Wstęp}

W ostatnich latach dokonał się znaczący postęp w obrazowaniu czynności metabolicznych nowotworów z wykorzystaniem pozytonowej tomografii emisyjnej (positron emission tomography - PET) [1, 2]. Metoda oparta jest na rejestracji promieniowania elektromagnetycznego emitowanego po anihilacji pozytonu z pierwiastka promieniotwórczego przyłączonego do dowolnego analogu metabolicznego podanego dożylnie, który jest następnie gromadzony w określonych komórkach i tkankach. Najczęściej w rutynowych badaniach diagnostycznych wykorzystuje się 18F-fluoro-2-dezoksy-Dglukozę (FDG), która transportowana jest do komórki w sposób identyczny jak glukoza. ${ }^{18}$ F-fluoro-2-dezoksy-D-glukoza jest metabolizowana w wielokrotnie większych ilościach niż w prawidłowych tkankach w większości typów nowotworów, których komórki charakteryzują się zwiększoną aktywnością glikolityczną. Próbą obiektywizacji wyników - wielkości metabolizmu FDG jest obliczanie wystandaryzowanej wartości wychwytu FDG (standardized uptake value - SUV) w wybranym obszarze [3]. Aktualnie wykorzystywane są również inne niż FDG radioznaczniki, które znajdują zastosowanie w ocenie proliferacji komórek nowotworowych, procesów niedotlenienia i angiogenezy, apoptozy, transportu aminokwasów, czy też obrazowaniu receptorów dla różnych peptydów, hormonów lub przeciwciał [2]. Od 2000 r. badanie PET jest zastępowane przez połączony system obrazowania, w którym wynik badania czynnościowego nakładany jest na dokładne dane anatomiczne pochodzące z badania tomografii komputerowej (computed tomography CT). Badanie PET/CT charakteryzuje się większą trafnością diagnostyczną niż samo badanie PET lub CT w ocenie stopnia zaawansowania wielu nowotworów u dorosłych, zarówno przed leczeniem, jak i w jego trakcie, a szczególnie w rozpoznaniu wczesnego nawrotu choroby [4, 5]. Rozwój i ustalanie wskazań do badania PET i PET/CT u dzieci dokonuje się znacznie wolniej niż w medycynie dorosłych, ponieważ dowody przydatności tej metody obrazowania dotyczą głównie nowotworów, które rzadko występują poniżej 15. roku życia. Na zastosowanie PET u dzieci ma również wpływ ekspozycja na promieniowanie, odmienny niż u dorosłych rozkład FDG w organizmie dziecka, stres dziecka związany z badaniem i znieczulenie do badania [6-8].

\section{Choroba nowotworowa u dzieci}

Choroba nowotworowa u dzieci występuje znacznie rzadziej niż u dorosłych i stanowi ok. 1,5-3\% wszystkich rozpoznawanych nowotworów. Częstość występowania ocenia się na 130-140 przypadków na 1 mln dzieci do 14. roku życia. W Polsce można oczekiwać od 1100 do 1200 nowych zachorowań rocznie [9]. Guzy nowotworowe u dzieci w odróżnieniu od dorosłych cha- 
Positron emission tomography (PET) is a novel, non-invasive function imaging method that is increasingly used for the primary staging of malignant diseases, detection of recurrence and assessment of therapeutic response. The combination of PET and computed tomography (PET/CT) improves the diagnostic capability of the method. The aim of this review is to present concisely the use of PET/CT in the pediatric oncology diagnostics. In the following chapters the author discusses the indication to the PET/CT examination according to the present knowledge and prospects of the PET development. PET/CT imaging can be effectively helpful for other useful diagnostic methods with are used in pediatric oncology. In Poland application of PET/CT should find wider use especially in children with lymphomas, central nervois system tumors, neuroblastoma, Wilms tumor, bone and soft tissue tumors.

Key words: positron emission tomography, computed tomography, pediatric oncology. rakteryzują się bardziej agresywnym metabolizmem, wczesnym i częstszym występowaniem przerzutów, inną lokalizacją oraz odmienną budową histopatologiczną. Najczęstszymi nowotworami u dzieci są białaczki, stanowiące ok. 1/3 wszystkich zachorowań na nowotwory u dzieci. Do najczęściej występujących guzów litych u dzieci zalicza się: guzy ośrodkowego układu nerwowego, chłoniaki, nerwiaki zarodkowe współczulne, nowotwory nerek, nowotwory kości i mięsaki tkanek miękkich. Rozszerzenie diagnostyki tych nowotworów o badanie PET/CT może zwiększyć szansę dziecka na wyleczenie lub skuteczniejsze leczenie. Poza dostarczeniem informacji strukturalnych, czynnościowych, metabolicznych i molekularnych o nowotworze zaletą metody PET jest bezinwazyjna i jednoczesna ocena całego ciała dziecka.

\section{Odrębności fizjologiczne u dzieci a badanie techniką pozytonowej tomografii emisyjnej}

Dystrybucja podanych dożylnie radioznaczników w organizmie dziecka jest inna niż u dorosłych [8,10]. 18F-fluoro-2-dezoksy-D-glukoza może być fizjologicznie gromadzona w narządach twarzoczaszki, sercu, piersiach, grasicy, śledzionie, przewodzie pokarmowym, narządzie rodnym, układzie moczowym, szpiku kostnym, mięśniach i tkance tłuszczowej brunatnej. Znacznik częściej niż u dorosłych gromadzony jest także w łagodnych guzach nowotworowych. Z tych powodów interpretacja wyników badania FDG PET/CT jest trudniejsza. Dodatkowo metoda u dzieci obarczona jest większą liczbą artefaktów. Meier i wsp. [10] analizowali obrazy wątroby, śledziony, trzustki, żołądka, jelita cienkiego, okrężnicy i odbytnicy w badaniach CT, PET i PET/CT u dzieci i dorosłych. Zmiany objętości narządów jamy brzusznej i/lub zmniejszenie metabolizmu glukozy w tkankach tych narządów korelowały z wiekiem badanych osób. Wychwyt FDG w ośrodkowym układzie nerwowym jest statystycznie znamiennie zależny od wieku dziecka [7].

W onkologii pediatrycznej podejmowane są próby powszechniejszego zastosowania badania PET/CT w rozpoznawaniu i ocenie stopnia klinicznego zaawansowania nowotworu, monitorowaniu jego leczenia, prognozowaniu przebiegu schorzenia oraz planowaniu radioterapii [6]. Tatsumi i wsp. [11] na podstawie analizy 151 badań FDG PET/CT u 55 dzieci z różnymi nowotworami umiejscowionymi poza ośrodkowym układem nerwowym stwierdzili, że metoda PET jest dokładniejsza w porównaniu z badaniami CT lub rezonansem magnetycznym (magnetic resonance imaging - MRI) i dostarcza dodatkowych informacji w ponad 1/3 przypadków. Kleis i wsp. [12] wykazali natomiast znamiennie większą czułość badania PET/CT niż PET w diagnostyce przerzutów odległych oraz większą specyficzność w rozpoznaniu przerzutów do płuc o średnicy powyżej 0,5 cm oraz do węzłów chłonnych o średnicy poniżej $1 \mathrm{~cm}$ niż konwencjonalne badanie CT. Również wstępne wyniki zastosowania FDG PET/CT u 36 dzieci z guzami jamy brzusznej wskazują na wartość kliniczną metody [13].

\section{Guzy ośrodkowego układu nerwowego}

Guzy ośrodkowego układu nerwowego u dzieci stanowią ok. 20\% wszystkich zachorowań na nowotwory i drugą co do częstości występowania grupę nowotworów po białaczkach. Nowotwory te wywodzą się głównie z tkanki nerwowo-nabłonkowej (glejaki, guzy z pierwotnych komórek nerwowych). Najczęstszym nowotworem złośliwym jest rdzeniak. W obrazowaniu guzów mózgu zastosowanie znajdują głównie badania CT i MRI. Rezonans magnetyczny jest badaniem bardziej czułym niż CT, zwłaszcza w przypadkach guzów zlokalizowanych w tylnej jamie czaszki [14]. Dotychczas zebrano u dzieci ograniczoną liczbę danych, które jedynie sugerują korelację badań FDG PET z wynikami badań histopatologicznych i przebiegiem klinicznym guzów mózgu u dzieci [15-17]. U chorych z astrocytomą o małym stopniu złośliwości stwierdzony wzmożony metabolizm FDG w guzie był dokładniejszym wskaźnikiem biologicznej aktywności guza niż badanie histopatologiczne [18]. Obrazowanie przy użyciu FDG PET w połączeniu z MRI było wykorzystane u dzieci 


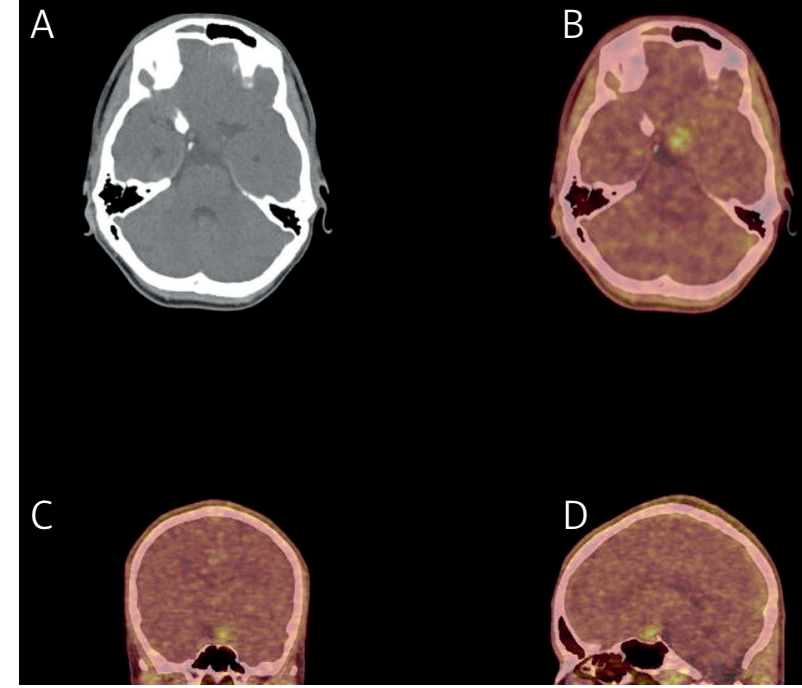

Ryc. 1. Chory, lat 15, z guzem mózgu. Obraz głowy w CT w przekroju poprzecznym (A) oraz FLT PET/CT w przekroju poprzecznym (B), czołowym (C) i bocznym (D). Widoczny wychwyt FLT przez guz mózgu okolicy siodła tureckiego (Zakład Medycyny Nuklearnej Centrum Onkologii w Bydgoszczy)

Fig. 1. A 15-year-old male patient with a brain tumor. Transaxial CT brain imaging (A). Transverse (B), coronal (C) and lateral (D) FLA $P E T / C T$ brain imaging. Increased focal FLA uptake in the brain tumor located in the sella turcica area (Nuclear Medicine Department in the Oncology Center in Bydgoszcz)

w celu znalezienia optymalnego miejsca do biopsji stereotaktycznej guza mózgu [19]. Badanie FDG PET/CT obarczone jest dużymi trudnościami ze względu na fizjologiczny wysoki metabolizm glukozy w ośrodkowym układzie nerwowym. Znakowana fluorem tyrozyna (18F-fluoroetylo-Ltyrozyna - FET) czy węglem metionina ( ${ }^{11} \mathrm{C}$-metionina - MET) podobnie jak FDG jest wychwytywana przez guz w stopniu zależnym od zróżnicowania komórkowego nowotworu. Jednak przy śladowym metabolizmie w zdrowych tkankach ośrodkowego układu nerwowego wzmożone gromadzenie FET (ryc. 1.) lub MET daje jednoznaczną odpowiedź co do istnienia rozrostu złośliwego oraz wyznacza dokładne granice tego procesu. Wymienione radioznaczniki znajdują szersze zastosowanie w różnicowaniu zmian martwiczych lub bliznowatych związanych z leczeniem od zmian resztkowych lub wznowy miejscowej. Stwierdzany stopień metabolizmu w guzie w czasie leczenia pozwala na ocenę odpowiedzi na terapię, a także prognozowanie przebiegu choroby [20]. Inni autorzy uważają jednak, że ocena aktywności metabolicznej guza nie pozwala na określenie stopnia jego złośliwości, a słaby wychwyt FDG nie wyklucza zmian resztkowych po leczeniu [21]. Podsumowując - badanie PET/CT w guzach ośrodkowego układu nerwowego u dzieci może mieć zastosowanie w wyznaczeniu optymalnego miejsca do biopsji celowanej guza, ocenie leczenia i prognozowaniu choroby.

\section{Chtoniaki}

Chłoniaki stanowią trzeci pod względem częstości występowania, po białaczkach i guzach ośrodkowego układu ner- wowego, nowotwór złośliwy u dzieci. Chłoniaki nieziarnicze (non-Hodgkin's lymphoma - NHL) występują częściej niż ziarnica złośliwa (Hodgkin's disease - HD), a chłopcy chorują 3 razy częściej niż dziewczynki. NHL u dzieci występują w postaci guza zajmującego węzły chłonne lub narządy pozawęzłowe (śródpiersie przednie, jama brzuszna, głowa i szyja, kości lub skóra). Ziarnica złośliwa najczęściej ma lokalizację węzłową. Podstawą optymalnego postępowania w chłoniakach jest badanie histopatologiczne oraz ocena klinicznego stopnia zaawansowania choroby. Nowoczesne metody konwencjonalnego obrazowania, takie jak ultrasonografia, CT i MRI, charakteryzują się określoną czułością, swoistością i dokładnością diagnostyczną. Ocena kliniczna może być trudna, gdy proces nowotworowy zajmuje niepowiększone węzły chłonne, szpik kostny lub wątrobę. Inne ograniczenia obejmują brak możliwości różnicowania między zmianami nowotworowymi, blizną lub martwicą w badaniach kontrolnych po leczeniu. Zastosowanie PET w diagnostyce chłoniaków wiąże się ze zwiększonym wychwytem FDG przez nowotwór. Chłoniaki nisko zróżnicowane charakteryzują się większym wychwytem niż rozrost dobrze zróżnicowany. Pierwsze badania FDG PET u dzieci z chłoniakami zmieniały stopień zaawansowania nowotworu u 10-23\% chorych [22-24]. Montavers i wsp. [22] stwierdzili w badaniu FDG PET więcej ognisk chorobowych niż w konwencjonalnych metodach obrazowania. Również Kabickova i wsp. [24] u 55 chorych z HD stwierdzili większą czułość i swoistość badania FDG PET niż obrazowanie metodami konwencjonalnymi (CT i MRI) w ocenie klinicznego stopnia zaawansowania (odpowiednio 96,5\% i 87,55\%; 100,0\% i 60,0\%). Metoda FDG PET poprawiła skuteczność rozpoznawania zmian pozawęzłowych w śledzionie, kościach i szpiku kostnym. Natomiast Mody i wsp. [25] u 26 dzieci (14 - HD, 12 - NHL) uzyskali w badaniu FDG PET większą czułość (94\%) i swoistość (100\%) niż w badaniach CT lub MRI i scyntygrafii z galem $\left({ }^{67} \mathrm{Ga}\right.$ ) (odpowiednio 90\%, $88 \%$ ). Metoda PET była szczególnie użyteczna w różnicowaniu tkanki bliznowatej od zmian resztkowych po leczeniu. Aktualnie badania u dzieci wykonywane są metodą połączonego obrazowania FDG PET/CT. Miller i wsp. [26] u 31 dzieci (24 - HD, 7 - NHL) stwierdzili, że wynik badania FDG PET/CT zmienił kliniczny stopień zaawansowania choroby u 10 chorych (32\%) w porównaniu z badaniami konwencjonalnymi. Autorzy dodatkowo wykazali dużą wartość prognostyczną badania. Ocena po II kursie chemioterapii wskazywała, że ujemne wyniki badania FDG PET/CT były związane z długotrwałą remisją choroby, natomiast dodatnie wyniki przemawiały za nieskutecznym leczeniem. Również Kleis i wsp. [12] stwierdzili wysoką negatywną (95\%) i wysoką pozytywną wartość predykcyjną (96\%) badania FDG PET/CT w stopniowaniu chłoniaków w trakcie leczenia. Poza tym metoda PET wykorzystywana jest także do planowania radioterapii chłoniaków u dzieci $[27,28]$. Podsumowując - badanie FDG PET/CT powinno znajdować zastosowanie w ocenie stopnia klinicznego zaawansowania chłoniaków u dzieci jako metoda zastępująca konwencjonalne metody obrazowania oraz we wczesnej ocenie skuteczności terapii (ryc. 2.). Pozytonowa tomografia emisyjna pozwala na różnicowanie zmian związanych z leczeniem od 
zmian resztkowych i wznowy, bez stosowania inwazyjnych metod diagnostycznych [29].

\section{Nerwiak zarodkowy wspótczulny}

Nerwiak zarodkowy współczulny (neuroblastoma - NBL) jest nowotworem złośliwym pochodzącym z komórek, z których w prawidłowych warunkach powstają nadnercza i układ współczulny. Jest to najczęstszy guz lity u dzieci, który występuje poza ośrodkowym układem nerwowym. Stanowi 7-10\% wszystkich nowotworów wieku rozwojowego i rzadko występuje po 5. roku życia. Najczęstszym umiejscowieniem ogniska pierwotnego jest przestrzeń zaotrzewnowa jamy brzusznej, tylne śródpiersie, szyja i miednica. Przerzuty występują stosunkowo wcześnie, do szpiku kostnego, kości i wątroby. W ocenie rozległości ogniska pierwotnego oraz w wykrywaniu przerzutów wykonywane są: ultrasonografia jamy brzusznej, badanie radiologiczne klatki piersiowej, CT, MRI i scyntygrafia [29]. Nerwiaki zarodkowe współczulne są aktywnymi metabolicznie guzami wychwytującymi FDG. Shulkin i wsp. [31] wzmożone gromadzenie radioznacznika w ognisku pierwotnym i zmianach przerzutowych stwierdzili u 16 z 17 badanych. Wyniki badania FDG PET były zgodne ze scyntygrafią z użyciem metajodobenzyloguanidyny znakowanej jodem (123|-MIGB). W obrazowaniu choroby resztkowej wartość kliniczna scyntygrafii była jednak większa. Inne badania sugerują, że zastosowanie hydroksyefedryny znakowanej węglem (11C-HDE PET/CT) jest bardziej czułe niż 123I-MIGB (99\% i 93\%) [32]. Ganglioneuroma i ganglioblastoma wychwytują również dihydroksyfenyloalaninę znakowaną fluorem (18F-DOPA), która w najbliższej przyszłości może zastąpić FDG w diagnostyce tych guzów [33]. Badanie FDG PET/CT było przydatne także w rozpoznaniu przerzutów NBL do opon mózgowych [34] oraz rozsiewu choroby przy ujemnym wyniku badania 123I-MIBG [35]. Poza tym u dzieci z nerwiakowłókniakowatością metoda może być wykorzystana w różnicowaniu guzów łagodnych od złośliwych. Ostatnia analiza porównawcza 60 dzieci z NBL wykazała przewagę badania FDG PET nad 123|-MIBG w ocenie choroby w I i II stopniu zaawansowania, a 123|-MIBG w wyższych stopniach zaawansowania oraz ocenie odpowiedzi na leczenie [36]. Obecnie przyjmuje się, że FDG PET/CT znajduje zastosowanie u dzieci z NHL w dokładniejszej ocenie niejednoznacznych zmian stwierdzanych w konwencjonalnych metodach obrazowania, a których nie potwierdzono przy użyciu scyntygrafii z użyciem ${ }^{123}$ I-MIBG.

\section{Nowotwory nerek}

Nerczak płodowy (guz Wilmsa) jest najczęstszym nowotworem złośliwym nerki u dzieci. W 5-7\% przypadków występuje równocześnie w obu nerkach. Najczęściej rozpoznawany jest w wieku przedszkolnym [37]. Po raz pierwszy wychwyt FDG w guzie Wilmsa stwierdzili Szulkin i wsp. [38]. Misch i wsp. [39] w ocenie stopnia zaawansowania choroby nowotworowej u 12 dzieci z guzem Wilmsa przed leczeniem wykazali zbliżoną wartość kliniczną FDG PET/CT do konwencjonalnych badań obrazowych. Metoda PET/CT miała jednak większą przydatność diagnostyczną w rozpoznaniu nawrotu nowotworu po leczeniu w 1 na 3 przypad-

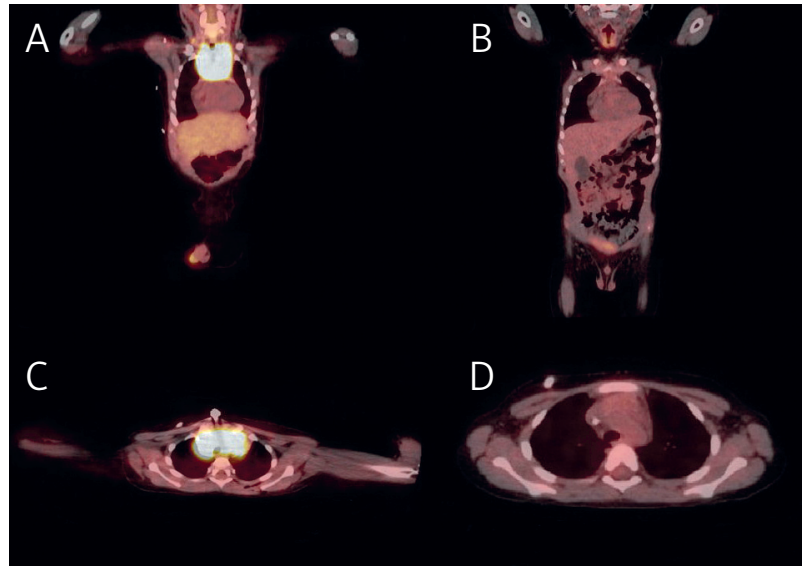

Ryc. 2. Chory, lat 5, z chłoniakiem śródpiersia odpowiadającym na leczenie. Obraz FDG PET/CT tułowia w przekroju czołowym (A) i klatki piersiowej w przekroju poprzecznym (C) przed leczeniem oraz po chemioterapii (B, D) (Zakład Medycyny Nuklearnej Centrum Onkologii w Bydgoszczy)

Fig. 2. A 5-year-old male patient with the mediastinum lymphoma, responsing to therapy. Coronal FDG PET/CT of the trunk $(A)$ and transverse CT (C) pre- and post-chemotherapy $(B, D)$ (Nuclear Medicine Department in the Oncology Center in Bydgoszcz)

ki oraz resztkowego guza u 2 na 5 chorych. Dodatkowo autorzy stwierdzili dodatnią korelację wartości SUV ze stopniem zróżnicowania histopatologicznego. Obecnie można przyjąć, że badanie FDG PET/CT ma potencjalne zastosowanie w ocenie stopnia zaawansowania guza Wilmsa, ocenie skuteczności jego leczenia, rozpoznaniu wznowy procesu nowotworowego oraz planowaniu radioterapii [40].

\section{Nowotwory kości}

Nowotwory złośliwe kości stanowią ok. 7\% wszystkich nowotworów wieku dziecięcego. U dzieci występuje głównie mięsak kościopochodny (osteosarcoma) i mięsak Ewinga (sarcoma Ewing). Oba nowotwory rozpoznawane są częściej u chłopców. Główną lokalizacją osteosarcoma jest okolica przynasadowa kości długich, zwłaszcza stawu kolanowego. Mięsak Ewinga umiejscawia się najczęściej w kościach kończyn dolnych, ale zajmuje również kości płaskie miednicy i tułowia. Podstawą rozpoznania i oceny stopnia zaawansowania tych nowotworów jest badanie radiologiczne, CT, MRI i scyntygrafia kości. W obu przypadkach guzów kości obowiązuje rozpoznanie histopatologiczne, a następnie terapia skojarzona, obejmująca chemioterapię, postępowanie chirurgiczne i radioterapię [41]. Franzius i wsp. [42] wykazali u 38 chorych z mięsakiem Ewinga większą skuteczność FDG PET w rozpoznaniu przerzutów do kości w porównaniu ze scyntygrafią kości, natomiast mniejszą czułość u 32 dzieci z kostniakomięsakiem. Natomiast Volker i wsp. [43] u 23 chorych z mięsakiem Ewinga i 12 chorych z kostniakomięsakiem stwierdzili większą czutość FDG PET niż metod obrazowania konwencjonalnego w rozpoznaniu przerzutów do węzłów chłonnych (95\% i $25 \%$ ) oraz naciekania kości (90\% i 57\%). W innych badaniach wykazano zgodność badania FDG PET u dzieci z guza- 


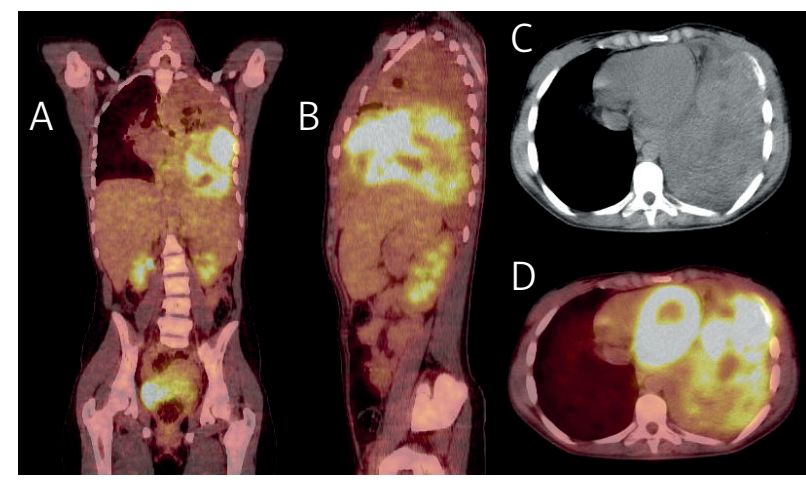

Ryc. 3. Chora, lat 16, z guzem Ewinga. Obraz FDG PET/CT tułowia w przekroju czołowym (A) i bocznym (B). Obraz CT (C) i FDG PET/CT (D) klatki piersiowej w przekroju poprzecznym. Widoczny wychwyt FDG przez guz lewej połowy klatki piersiowej (Zakład Medycyny Nuklearnej Centrum Onkologii w Bydgoszczy)

Fig. 3. A 16-year-old female patient with Ewing's sarcoma. Coronal (A) and latheral (B) FDG PET/CT images of the trunk. Transverse $C T$ (C) and FDG PET/CT (D) of the thorax. FDG uptake in left thorax sarkoma (Nuclear Medicine Department in the Oncology Center in Bydgoszcz)

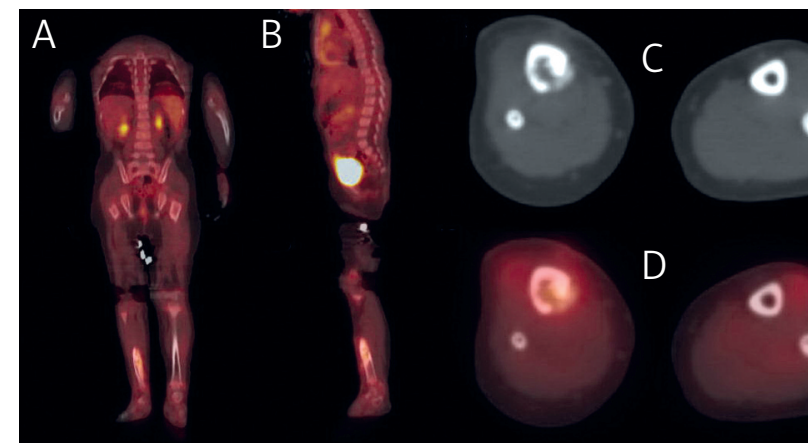

Ryc. 4. Chora, lat 2, z mięsakiem prążkowanokomórkowym, 2 miesiące po leczeniu operacyjnym. Obraz FDG PET/CT całego ciała w przekroju czołowym (A) i bocznym (B) oraz CT (C) i FDG PET/CT (D) podudzia prawego $\mathrm{w}$ przekroju poprzecznym. Widoczny ogniskowy wychwyt FDG w podudziu prawym (wznowa miejscowa) (Zakład Medycyny Nuklearnej Centrum Onkologii w Bydgoszczy) Fig. 4. A 2-year-old female patient with rhabdomyosarcoma, 2 months after surgical therapy. Coronal (A) and lateral (B) FDG PET/CT images of the whole body. Transverse CT (C) and FDG $P E T / C T(D)$ of the right shank. Focal FDG uptake in the right tibia (local recurrence) (Nuclear Medicine Department in the Oncology Center in Bydgoszcz)

mi złośliwymi kości w odpowiedzi na chemioterapię i wynikiem badania histopatologicznego usuniętego guza [44]. W retrospektywnej ocenie 55 dzieci z guzami kości w badaniu FDG PET u 22\% chorych stwierdzono przerzuty [45]. Obrazowanie FDG PET/CT było przydatne głównie w rozpoznaniu nawrotów miejscowych [46]. Ostatecznie wartość kliniczna FDG PET/CT w guzach kości u dzieci nie jest dokładnie określona, należy sądzić, że metoda może być użyteczna w ocenie stopnia klinicznego zaawansowania guza przed leczeniem (ryc. 3.), monitorowaniu odpowiedzi na terapię i przewidywaniu dalszego przebiegu choroby.

\section{Mięsaki tkanek miękkich}

Mięsaki tkanek miękkich stanowią ok. 8\% wszystkich nowotworów złośliwych u dzieci. Najczęstszym jest mięsak prążkowanokomórkowy (rhabdomyosarcoma - RMS). Zasadniczymi metodami obrazowania są: badanie ultrasonograficzne, CT i MRI, które oceniają wielkość guza i sposób jego naciekania. W diagnostyce przerzutów wykonuje się zdjęcia radiologiczne i CT klatki piersiowej, jak również badanie szpiku i scyntygrafię kości. Wykrycie ogniska pierwotnego i przerzutów możliwe jest również w badaniu FDG PET $[47,48]$. Badanie FDG PET może być przydatne także w monitorowaniu leczenia. Schuetze i wsp. [49] stwierdzili, że u chorych z mięsakami tkanek miękkich wartości SUV przed leczeniem i jego zmiany po leczeniu neoadiuwantowym pozwalają na identyfikację chorych z dużym ryzykiem nawrotu guza. Również Peng i wsp. [50] wykazali istotne zmniejszenie wychwytu FDG przez RMS u dzieci, u których uzyskano dobrą odpowiedź na terapię i długotrwałą remisję. Utrzymywanie się nieprawidłowego gromadzenia znacznika koreluje z nieskutecznym leczeniem lub wczesnym nawrotem choroby (ryc. 4.). Klem i wsp. [51] w retrospektywnej analizie 24 chorych z RMS, u których wykonano FDG PET, stwierdzili wysoką specyficzność metody (95\%) w rozpoznawaniu przerzutów do węzłów chłonnych. Ustalenie wartości klinicznej FDG PET/CT w ocenie klinicznego stopnia zaawansowania i monitorowania w nowotworach tkanek miękkich u dzieci wymaga jednak dalszych prospektywnych badań na większej grupie chorych.

\section{Inne nowotwory}

Guzy kory nadnerczy należą do rzadkich nowotworów u dzieci. Wstępne badania sugerują, że guzy kory nadnerczy są aktywne metabolicznie, a badanie FDG PET może być przydatne w wykrywaniu nawrotu choroby oraz przerzutów. Wyniki fałszywie ujemne stwierdzane są często w przypadku małych zmian nowotworowych [52]. Aktualnie uważa się, że większą wartość kliniczną u dzieci z pheochromocytoma i zespołami mnogich nowotworów gruczołów dokrewnych ma badanie 18F-DOPA PET/CT [53]. Wątrobiak zarodkowy (hepatoblastoma) jest najczęstszym pierwotnym złośliwym guzem wątroby u dzieci, występującym głównie w pierwszych 3 latach życia. W związku ze zwiększoną aktywnością glikolityczną guzów wątroby FDG PET może być przydatną metodą w rozpoznaniu ogniska pierwotnego i odległych przerzutów oraz w ocenie odpowiedzi na leczenie. Mody i wsp. [54] u 6 z 7 chorych z pierwotnym guzem wątroby stwierdzili nieprawidłowy wychwyt FDG. Zwrócili uwagę, że badanie FDG PET może być użyteczne zwłaszcza w ocenie leczenia u chorych z prawidłowymi wartościami antygenu rakowopłodowego ( $\alpha$-fetoproteina - AFP).

\section{Podsumowanie}

Zastosowanie badania PET/CT w nowotworach u dzieci będzie wzrastało wraz z większą dostępnością metody oraz wprowadzeniem nowych skanerów i radioznaczników. Potencjalne wskazania do badania u dzieci obejmują: ocenę klinicznego stopnia zaawansowania nowotworu (staging, restaging), wyznaczanie miejsca do biopsji guza, oce- 
nę wczesnej i późnej odpowiedzi na leczenie, prognozowanie przebiegu choroby nowotworowej, planowanie radioterapii, wyjaśnienie niejednoznacznych lub sprzecznych wyników konwencjonalnych metod obrazowania. Aktualnie FDG PET/CT u dzieci ma największą wartość kliniczną w chłoniakach, guzach kości i tkanek miękkich oraz nowotworach pochodzenia embrionalnego. Najbliższe lata powinny dostarczyć dokładniejszej analizy oceny wartości klinicznej tej metody w pediatrii onkologicznej i zaowocować jej szerszym wprowadzeniem w Polsce.

\section{Piśmiennictwo}

1. Townsend DW. Positron emission tomography/computed tomog raphy. Semin Nucl Med 2008; 38: 152-66.

2. Wood KA, Hoskin PJ, Saunders MI. Positron emission tomography in oncology: a review. Clinical Oncology 2007; 19: 237-55.

3. Thie JA. Understanding the standardized uptake value, its method, and implication for usage. J Nucl Med 2004; 45: 1431-4.

4. Czernin J, Allen-Auerbach M, Schelbert HR. Improvements in can cer staging with PET/CT: literature-based evidence as of septem ber 2006. J Nucl Med 2007; 48: 78S-88S.

5. Israel O, Kuten A. Early detection of cancer recurrence: $18 \mathrm{~F}-\mathrm{FDC}$ $\mathrm{PET} / \mathrm{CT}$ can make a difference in diagnosis and patient care. J Nuc Med 2007; 48: 28S-35S.

6. Jadvar H, Connolly LP, Fahey FH, Shulkin BL. PET and PET/CT in pedi atric oncology. Semin Nucl Med 2007; 37: 316-31.

7. Stauss J, Franzius C, Pfuger T, et al. Guidelines for ${ }^{18}$ F-FDG PET and PET-CT imaging in paediatric oncology. Eur J Nucl Med Mol Imaging 2008; 35: 1581-88.

8. Shammas A, Lim R, Charron M. Pediatric FDG PET/CT: physiologic uptake, normal variants, and benign conditions. Radiographics 2009 29: 1467-86.

9. Kowalczyk JR. Epidemiologia nowotworów złośliwych u dzieci. W Onkologia i hematologia dziecięca. Chybicka A, Sabiczo-Birkowska K (red.). Wydawnictwo Lekarskie PZWL, Warszawa 2008; 3-7.

10. Meier JM, Alavi A, Iruvuri S, et al. Assessment of age-related changes in abdominal organ structure and function with computer tomog raphy and positron emission tomography. Semin Nucl Med 2007; 37: 154-72.

11. Tatsumi M, Miller JH, Wahl RL. 18F-FDG PET/CT in evaluating nonCNC pediatric malignancies. J Nucl Med 2007; 48: 1923-31.

12. Kleis M, Daldrup-Link H, Matthay K, et al. Diagnostic value of PET/C for staging and restaging pediatric tumors. Eur J Nucl Med Mol Imag ing 2009; 36: 23-36.

13. Murphy JJ, Tawfeeq M, Chang B, Nadel H. Early experience with $\mathrm{PET} / \mathrm{CT}$ scan in the evaluation of pediatric abdominal neoplasms. J Pediatr Surg 2008; 43: 2186-92.

14. Perek D. Nowotwory ośrodkowego układu nerwowego. W: Onkologia i hematologia dziecięca. Chybicka A, Sabiczo-Birkowska K (red.). Wydawnictwo Lekarskie PZWL, Warszawa 2008; 323-45.

15. Molloy PT, Belasco J, Nago K, et al. The role of FDG-PET imaging in the clinical management of pediatric brain tumors. J Nucl Med 1999; 40: 129 .

16. Gururangan S, Hwang E, Herndon JE. [18F]fluorodeoxyglucose positron emission tomography in patients with medulloblastoma. Neurosurgery 2004; 55: 1280-8.

17. Wang SX, Boethus J, Ericson K. FDG-PET on irradiated brain tumor: ten years summary. Acta Radiol 2006; 47: 85-90.

18. Molloy PT, Defeo R, Hunter J, et al. Excellent correlation of FDG-PET imaging with clinical outcome in patients with neurofibromatosis type I and low grade astrocytomas. J Nucl Med 1999; 40: 129P.

19. Pirotte B, Goldman S, Salzberg S, et al. Combined positron emission tomography and magnetic resonance imaging for planning of stereotactic brain biopsies in children: experience in 9 cases. Pediatr Neurosurg 2003; 38: 146-55.

20. Patil S, Biassoni L, Borgwardt L. Nuclear medicine in pediatric neu rology and neurosurgery: epilepsy and brain tumors. Semin Nucl Med 2007; 37: 357-81.
21. Smith RJ, Laningham FH, Laughton S, et al. Metabolic/histologic characterization of pediatric CNS neoplasms. J Nucl Med 2007; 48: 117P-118P.

22. Montravers F, McNamara D, Landman-Parker J, et al. [18F]FDG in childhood lymphoma: clinical utility and impact on management. Eur J Nucl Med Mol Imaging 2002; 29: 1155-65.

23. Depas G, De Barsy C, Jerusalem G, et al. 18F-FDG PET in children with lymphomas. Eur J Nucl Med Mol Imaging 2005; 32: 31-8.

24. Kabickova E, Sumerauer D, Cumlivska E, et al. Comparison of ${ }^{18} \mathrm{~F}$ FDG-PET and standard procedures for the pretreatment disease. Eur J Nucl Med Mol Imaging 2006; 33: 1025-31.

25. Mody RJ, Bui Ch, Hutchinson RJ, Frey KA, Shulkin BL. Comparison of 18 F Flurodeoxyglucose with Ga-67 scintigraphy and conventional imaging modalities in pediatric lymphoma. Leuk Lymphoma 2007; 48: 51-5.

26. Miller E, Metser U, Avrahami G, et al. Role of ${ }^{18} \mathrm{~F}-\mathrm{FDG}$ PET/CT in staging and follow-up of lymphoma in pediatric and joung adult patients. J Comput Assist Tomogr 2006; 28: 689-94.

27. Lee YK, Cook G, Flower MA, et al. Addition of 18 F-FDG-PET scan to radiotherapy planning of thoracic lymphoma. Radiother Oncol 2004; 73: $277-83$.

28. Hutchings M, Loft A, Hansen M, Berthelsen AK, Specht L. Clinical impact of FDG-PET/CT in the planning of radiotherapy for earlystage Hodgkin lymphoma. Eur J Hematol 2007; 135: 206-12.

29. Shankar A, Fiumara F, Pinkerton R. Role of FDG PET in the management of childhood lymphomas - case prove or is the jury still out? Eur J Cancer 2008; 44: 663-873.

30. Balwierz W. Nerwiak zarodkowy współczulny. W: Onkologia i hematologia dziecięca. Chybicka A, Sabiczo-Birkowska K (red.). Wydawnictwo Lekarskie PZWL, Warszawa 2008; 357-74.

31. Shulkin BL, Hutchinson RJ, Castele VP, Yanik GA, Shapiro B, Sissin JC. Neuroblastoma: positron emission tomography with 2-[fluorine18]-fluoro-2-deoxy-D-glucose compared with metaiodobenzylguanidine scintigraphy. Radiology 1996; 199: 743-50.

32. Franzius C, Herman K, Weckesser M, Kopka K, Juergens KU, Vormoor J, Schober O. Whole-body PET/TK with ${ }^{11} \mathrm{C}$-metahydroxyephedrine in tumors of the sympathetic system: Feasibility study and comparison with ${ }^{123}$ I-MIBG SPECT-CT. J Nucl Med 2006; 47 : 1635-42.

33. Tzen K, Wang L, Lu M. Characterization of neuroblastic tumors using F-18-DOPA PET. J Nucl Med 2007; 48: 154P.

34. Chawla M, Reddy R, Kumar R, Das CJ, Agarwala S, Tiwari AM, Malhotra A, Kumar R. PET-CT detection of meningeal metastasis in neuroblastoma. Pediatr Surg Int 2009; 25: 211-5.

35. Colavolpe C, Guedj E, Cammilleri S, Taieb D, Mundler O, Coze C. Utility of FDG-PET/CT in the follow-up of neuroblastoma with became MIBG-negative. Pediatr Blood Cancer 2009; 5: 828-31.

36. Sharp SE, Skulkin BL, Furman WL, Gelfand MJ, Salisbury S, Furman WL. ${ }^{123}$ I-MIBG scintigraphy and 18 F-FDG PET in neuroblastoma. J Nucl Med 2009; 50: 1237-43.

37. Sawicz-Birkowska K. Nowotwory nerek. W: Onkologia i hematologia dziecięca. Chybicka A, Sabiczo-Birkowska K (red.). Wydawnictwo Lekarskie PZWL, Warszawa 2008; 375-92.

38. Shulkin BL, Chang E, Strouse PJ, et al. FDG PET studies of Wilms tumors. J Pediatr Hem Oncol 1997; 19: 224-338.

39. Misch D, Steffen IG, Schonberger S, et al. Use of positron emission tomography for staging, preoperative response assessment and posttherapeutic evaluation in children with Wilms tumor. J Nucl Med Mol Imaging 2008; 35: 1642-50.

40. Owns CM, Brisse HJ, Olsen OE, Begent J, Smets AM, Bilateral disease and new trends in Wilms tumour. Pediatr Oncol 2008; 38: 30-9.

41. Woźniak W. Pierwotne złośliwe nowotwory kości. W: Onkologia i hematologia dziecięca. Chybicka A, Sabiczo-Birkowska K (red.). Wydawnictwo Lekarskie PZWL, Warszawa 2008; 437-56.

42. Franzius TL, Sciuk J, Daldrup-Link HE, et al. FDG-PET for detection of osseous metastases from malignant primary bone tumors: comparison with bone scintigraphy. Eur J Nucl Med 2000; 27: 1305-11.

43. Volker T, Denecke T, Steffen I, Misch D, Schonberger S, Plotkin M, Ruf J, Furth Ch, et al. Positron emission tomography for staging of pediatric sarcoma patients: results of a prospective multicenter trial. J Clin Oncol 2007: 34: 5435-41. 
44. Hawkins DS, Schuetze SM, Butrynski JE, et al. [ ${ }^{18}$ F]fluorodeoxyglucose positron emission tomography predicts outcome for Ewing sarcoma family of tumors. J Clin Oncol 2005; 23: 8828-34.

45. Kneisl JS, Patt JC, Johanson JC, et al. Is PET useful in detecting occult nonpulmonary metastases in pediatric bone sarcomas? Clin Ostop Relat Res 2006; 450: 101-4.

46. Ben Arush MW, Israel O, Postovsky S, Militianu D, Meller I, Zaidman I, Sapir AE, Shalom R. Positron emission tomography/com-

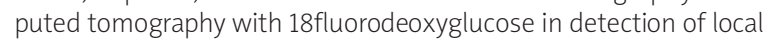
recurrence and distant metastases of pediatric sarcoma. Pediatr Blood Cancer 2007; 49: 901-5.

47. Ben Arush MW, Israel O, Kedar Z, et al. Detection of isolated distant metastasis in soft tissue sarcoma by fluorodeoxyglucose positron emission tomography: case raport. Pediatr Hematol Oncol 2001; 18: 295-8.

48. Ben Arush MW, Bar Shalom R, Potovsky S, Militisnu D, Haimi M, Zaidman I, Israel O. Assessing the use FDG-PET In the detection of regional and metastatic nodes in alveolar rhabdomyosarcoma of extremities. J Pediatr Hematol Oncol 2006; 28: 440-5.

49. Schuetze SN, Rubin BP, Vernon C, et al. Use of positron emission tomography in localized extremity soft tissue sarcoma treated with neoadjuvant chemiotherapy. Cancer 2005; 103: 339-48.

50. Peng F, Rabkin G, Muzik O. Use of 2-deoxy-[F-18]-fluoro-D-glucose positron emission tomography to monitor therapeutic response by rhabdomyosarcoma in children: raport of a retrospective case. Clin Nucl Med 2006; 31: 394-7.

51. Klem ML, Grewal RK, Wexler LH, et al. PET for staging in rhabdomyosarcoma: An evaluation of PET as an adjunct to current staging tools. J Pediatr Hematol Oncol 2007; 29: 9-14.

52. Mackie GC, Shulkin BL, Ribeiro RC, et al. Use of [18F] fluorodeoxyglucose positron emission tomography in evaluating locally recurrent and metastatic adrenocortical carcinoma. J Clin Endocrinol Metab 2006; 91: 2665-267.

53. Mottaghy FM, Karges W, Zeich K, et al. [18F]Dihydroxyphenylalanine PET-CT in pheochromocytoma. J Nucl Med 2007; 48: 154P.

54. Mody RJ, Pohlen JA, Malde S, et al. FDG-PET for the study of primary hepatic malignancies in children. Pediatr Blood Cancer 2006; 47: 51-5.

\section{Adres do korespondencji}

\section{dr n. med. Zbigniew Kula}

Zakład Endoskopii

Centrum Onkologii im. prof. F. Łukaszczyka

ul. Romanowskiej 2

85-795 Bydgoszcz

tel. +48 523743274

e-mail: zbigniew.kula@co.bydgoszcz.pl 